Research Article

\title{
Gender Disparity in Health Expenses, Health Insurance Financing and Out-of-Pocket Expenses for Inpatient Care in India
}

\author{
Parimala Mohanty', Pratap Kumar Jena ${ }^{2}$, Jugal Kishore ${ }^{3}$ \\ ${ }^{1} \mathrm{MPH}$ Scholar, ${ }^{2}$ Associate Professor, School of Public Health, KIIT Deemed to be University, Bhubaneswar, India. \\ ${ }^{3}$ Professor and Head, Department of Community Medicine, Vardhaman Mahavir Medical College \& Safdarjung Hospital, New \\ Delhi.
}

DOI: https://doi.org/10.24321/2454.325X.201918

\section{I $\quad \mathbf{N} \quad \mathbf{F} \quad \mathbf{O}$}

\author{
Corresponding Author: \\ Jugal Kishore, Department of Community \\ Medicine, Vardhaman Mahavir Medical \\ College \& Safdarjung Hospital, New Delh \\ E-mail Id: \\ drjugalkishore@gmail.com \\ Orcid Id: \\ https://orcid.org/0000-0001-6246-5880 \\ How to cite this article: \\ Mohanty P, Jena PK, Kishore J. Gender \\ Disparity in Health Expenses, Health Insurance \\ Financing and Out-of-Pocket Expenses for \\ Inpatient Care in India. Int J Preven Curat \\ Comm Med 2019; 5(3): 3-10.
}

Date of Submission: 2019-08-27

Date of Acceptance: 2019-09-25

\section{$\begin{array}{llllllll}\text { A } & \text { B } & \mathbf{S} & \mathbf{T} & \mathbf{R} & \mathbf{A} & \mathbf{C} & \mathbf{T}\end{array}$}

Background: Socially constructed gender and the economic status have strong bearing on the household out-of-pocket health expenditure and resulting in unequal distribution of health services.

Objective: To assess the gender disparity in total health expenses, health insurance financing and out-of-pocket expenses for various ailments during inpatient care in India.

Methods: The nationally representative health consumption data from the $71^{\text {st }}$ Round (2014) of National Sample Survey Organization was analyzed. Socio-economic status was estimated using 'Principal Component Analysis'. Respective sample weights have been applied in the calculation of the results. The analysis is done with $\mathrm{R}$ studio software. The stratified analysis of gender difference in financing for total heath expenses, insurance, out-of-pocket expenses was accessed across three socio-economic-status groups to understand gender and its association between social statuses.

Result: The average total health expense for male inpatient care of various ailments was ranged between Rs. 9589.5 and Rs. 85857.9, whereas for female the average health expenses were ranged between Rs. 7847.8 and Rs. 55604.2. The average insurance financing for male inpatient care of various ailments was ranged between Rs. 906.6 and Rs. 10677.2 and for females, it ranged between Rs. 394.8 and Rs. 6063.2. The average OOPEs for male inpatient care of various ailments were ranged between Rs. 9141.8 and Rs. 75180.6, similarly for females, the average OOPEs ranged between Rs. 7459.3 and 49583.2 . The average total insurance financing in lower SES for inpatient care was usually higher for males than females in low (1.3 to 19.9 times), middle (1.2 to 3.4 times) and high (1.1 to 2.4 times) SES groups and the average OOPEs for inpatient care was higher for males than females in low (1.1 to 2.2 times), middle (1.1 to 1.7 times) and high (1.1 to 2.3 times) SES groups for most of the ailments except a few.

Conclusion: Overall insurance coverage is low particularly for females. The gender disparity in lower average health expenses, average insurance financing and out-of-pocket expenses during inpatient care in India is a concern, which requires policy interventions to promote equity.

Keywords: Gender Disparity, Insurance, Healthcare Expenditures, NSSO 


\section{Background}

The key determinants of uneven distribution of health status are situated outside the health sector in the form of socio-economic conditions..$^{1,2}$ Among these, gender and economical status have been extensively debated. Despite of socio-economic development in India, female feticide and excess female mortality still remains a concern. ${ }^{1}$ Gender disparity in nutritional status, immunization coverage, treatment-seeking behavior, etc., is very common feature in India. ${ }^{2,3}$ For example, girl children are $7 \%$ less immunized than boys, ${ }^{4}$ women have less access to hospital treatment; and are subject to fewer hospitalizations before death. ${ }^{5}$ Untreated morbidity rates are higher among women than men, and a strong class gradient by gender is found for in-patient health care. Also, girls' access to health care depends heavily on the sex composition of siblings. ${ }^{6}$ Gender inequality is reflected in India's low ranking on the World Economic Forum's Gender Gap Index (GGI), 2014, with scores below average on parameters such as educational attainment (126 ${ }^{\text {th }}$ rank), economic participation ( $134^{\text {th }}$ rank) and health and survival (141 ${ }^{\text {th }}$ rank). ${ }^{7}$

Females constitute 70 per cent of the poor ${ }^{8}$ and the limited financial access along with gendered role in decision making is a key limitation to access healthcare services in lower middle income countries wherein the Out-ofPocket Expenditure (OOPE) constitutes a sizeable proportion of healthcare expenditure. ${ }^{9,10}$ Healthcare system in India is highly privatized and the main source of financing is OOPE. ${ }^{11,12}$ The OOPE may lead to distress financing and catastrophic health expenses for the households. It is seen that the average Health Care Expenditure (HCE) is lower for females and they are also discriminated, when health care expenses has to be paid for by borrowing, sale of assets, or contributions from friends and relatives..$^{13}$ In India it shows that HCE was systematically lower for women than for men across all socioeconomic subgroups, despite women suffering from a higher morbidity prevalence than men. ${ }^{14}$ The health economics literature suggests healthcare utilization provides better insights into the factors responsible for disparity in health status. ${ }^{15,16}$

However, there is limited data on gender disparity in diseasespecific OOPE following hospitalization in India leading to lack of evidence for gender balanced policy formulation. In this context, current study explores the gender disparity in health-care financing for different aliments in India using recently available nationally representative data from the National Sample Survey Organization (NSSO). ${ }^{17}$

\section{Methods}

In this study nationally representative secondary data from NSSO, $71^{\text {st }}$ Round (2014) on health consumption (18) was used. The health consumption sub-survey had covered 65,932 households and 0.33 million individual participants. The information on individual and household socio-economic backgrounds, ailments, utilization of healthcare services provided by public and private sectors, and health financing with its source had been collected. The survey adopted a stratified multistage sample design, using census villages for the rural areas and urban blocks for the urban areas as the First-Stage Units (FSUs), and households as the second-stage units. The participants provided a Self-Report illness in the survey. The reference period for inpatient and outpatient care was previous 365 days. ${ }^{18}$ In this study 88 types of ailments identified by NSSO were regrouped into seventeen broad categories excluding childbirth. Latter, obstetrics ailment was excluded during analysis as it comprises of only female participants. In this study 'Other' aliment includes the symptoms which don't fit into any of the above categories and those who couldn't even state the main symptom.

Using principal component analysis, availability of latrine, source of water and energy, were considered to identify three (low, middle and high) socio-economic groups. The gender disparity in hospitalization, inpatient healthcare expenses, insurance coverage and OOPEs were estimated. Respective sample weights have been applied in the calculation of the results. The analysis is done on $\mathrm{R}$ studio software (32-bit). ${ }^{19}$

\section{Result}

Overall the number of hospitalized patients was 39.17 million (Male: 19.36 million) during one year preceding the NSSO survey in 2014. It was observed that the top five causes of inpatient care among male were infection (27.4\%), injuries (16.1\%), gastrointestinal (10.8\%), cardiovascular $(9.3 \%)$ and psychiatric (6.3\%) diseases. Among females, the top five causes of inpatient care were infection (24.1\%), gastrointestinal $(11.6 \%)$, obstetric $(9.3 \%)$, genitourinary $(7.6 \%)$ and cardiovascular (7.5\%) diseases (Table 1).Only 18.5\% (male $21.4 \%$, female $18.3 \%$ ) of the hospitalized patients had insurance mostly from government funded schemes. Only $2 \%$ had self purchased insurance. The distribution of various ailments is given at Table 1.

Table I.Distribution of various ailments among inpatients

\begin{tabular}{|c|c|c|}
\hline Ailment Nature & Male N (\%) & Female N (\%) \\
\hline Infection & $5720(27.4)$ & $5046(24.1)$ \\
\hline Cancer & $323(1.2)$ & $451(2)$ \\
\hline Blood disorders & $332(1.4)$ & $493(2.4)$ \\
\hline
\end{tabular}




\begin{tabular}{|c|c|c|}
\hline Endocrinal disorders & $486(2.1)$ & $663(3)$ \\
\hline Psychiatric disorders & $1319(6.3)$ & $1107(5.4)$ \\
\hline Eye diseases & $775(4.2)$ & $815(5.4)$ \\
\hline Ear diseases & $81(0.5)$ & $102(0.5)$ \\
\hline Cardiovascular disorders & $1843(9.3)$ & $1426(7.5)$ \\
\hline Respiratory diseases & $1130(5.3)$ & $895(4.7)$ \\
\hline Gastrointestinal disorders & $2265(10.8)$ & $2474(11.6)$ \\
\hline Skin diseases & $198(0.9)$ & $192(0.9)$ \\
\hline Musculoskeletal disorders & $969(4.7)$ & $985(5.2)$ \\
\hline Genitourinary disorders & $1117(5.8)$ & $1594(7.6)$ \\
\hline Obstetric conditions & $0(0)$ & $1634(9.3)$ \\
\hline Sicknewborns & $179(1.1)$ & $123(0.6)$ \\
\hline Injuries & $3198(16.1)$ & $1321(6.5)$ \\
\hline Others & $561(2.6)$ & $638(3.3)$ \\
\hline
\end{tabular}

Note: The figures in parenthesis represent weighted percentage.

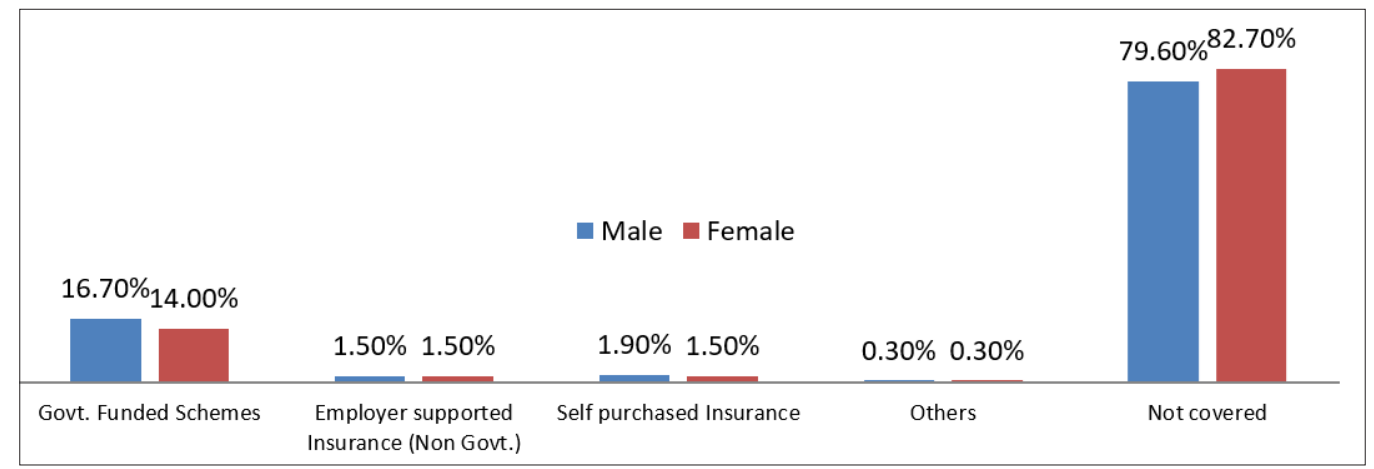

Figure I.Gender stratified coverage of health insurance among the hospitalized patients

Table 2.Ailment specific average health expenses, insurance financing and out of pocket expenses among inpatients in India

\begin{tabular}{|c|c|c|c|c|c|c|c|c|c|}
\hline \multirow{2}{*}{ Aliment Type } & \multicolumn{3}{|c|}{$\begin{array}{c}\text { Average Total Health } \\
\text { Expenses (in INR) }\end{array}$} & \multicolumn{3}{c|}{$\begin{array}{c}\text { Average Insurance Financing } \\
\text { (in INR) }\end{array}$} & \multicolumn{3}{c|}{$\begin{array}{c}\text { Average Out-of-Pocket } \\
\text { Expenses (in INR) }\end{array}$} \\
\cline { 2 - 12 } & Male & Female & $\boldsymbol{p}$-value & Male & Female & $\boldsymbol{p}$-value & Male & Female & $\boldsymbol{p}$-value \\
\hline Infection & 9589.5 & 7847.8 & 0.0001 & 906.6 & 394.8 & 0.37 & 9141.8 & 7459.3 & 0.0001 \\
\hline Cancer & 85857.9 & 55604.2 & 0.014 & 10677.2 & 6063.2 & 0.27 & 75180.6 & 49583.2 & 0.022 \\
\hline Blood disorders & 15357.5 & 17852.1 & 0.65 & 225.9 & 277 & 0.78 & 15131.5 & 17575.1 & 0.66 \\
\hline $\begin{array}{c}\text { Endocrinal } \\
\text { disorders }\end{array}$ & 19720.8 & 14269.9 & 0.005 & 1907.8 & 804 & 0.039 & 17831.9 & 13467.1 & 0.016 \\
\hline $\begin{array}{c}\text { Psychiatric } \\
\text { disorders }\end{array}$ & 29872.1 & 20267.9 & 0.0001 & 677.2 & 528.7 & 0.81 & 28251.8 & 19626.7 & 0.0001 \\
\hline $\begin{array}{c}\text { Eye disorders } \\
\text { Ear disorders }\end{array}$ & 11077.4 & 10293.9 & 0.28 & 924 & 790.5 & 0.58 & 10153.4 & 9503.4 & 0.35 \\
\hline $\begin{array}{c}\text { Cardiovascular } \\
\text { disorders }\end{array}$ & 44319.8 & 26271.6 & 0.0001 & 4013.4 & 2329.9 & 0.058 & 40389.2 & 23944.5 & 0.0001 \\
\hline $\begin{array}{c}\text { Respiratory } \\
\text { diseases }\end{array}$ & 13914 & 13336.5 & 0.64 & 707.9 & 865 & 0.64 & 13206 & 12471.5 & 0.54 \\
\hline
\end{tabular}




\begin{tabular}{|c|c|c|c|c|c|c|c|c|c|}
\hline $\begin{array}{c}\text { Gastrointestinal } \\
\text { disorders }\end{array}$ & 18852.6 & 17565.7 & 0.16 & 1510.9 & 723.6 & 0.015 & 17396.4 & 16844.2 & 0.51 \\
\hline Skin diseases & 16444.1 & 13408 & 0.23 & 1101.5 & 643.3 & 0.51 & 15342.6 & 12764.7 & 0.28 \\
\hline $\begin{array}{c}\text { Musculoskeletal } \\
\text { disorders }\end{array}$ & 24953.1 & 26231.8 & 0.59 & 1808.5 & 2698.6 & 0.32 & 23144.5 & 23533.3 & 0.86 \\
\hline $\begin{array}{c}\text { Genitourinary } \\
\text { disorders }\end{array}$ & 31130.5 & 23653.3 & 0.017 & 4796.8 & 1854.2 & 0.28 & 26352.9 & 21801.3 & 0.004 \\
\hline Sick new born & 20136.5 & 16031.9 & 0.24 & 115.6 & 0 & 0.23 & 20020.8 & 16031.9 & 0.26 \\
\hline Injuries & 29711 & 23380.3 & 0.002 & 1743.2 & 1129.5 & 0.19 & 28010.2 & 22250.8 & 0.003 \\
\hline Others & 27171.8 & 22783.4 & 0.14 & 2410.7 & 751.3 & 0.014 & 24812.2 & 22032.1 & 0.34 \\
\hline
\end{tabular}

Overall, the average total health expense for male inpatient care of various ailments was ranged between Rs.9589.5and Rs. 85857.9. Similarly, for female inpatients the average health expenses was ranged between Rs. 7847.8 and Rs. 55604.2. The average total health expense for inpatient care was higher for males than females (1.1 to 1.7 times) for all ailments except for blood, ear and musculoskeletal disorders. The gender difference in total health expenses was significant for ailments like infection, cancer, endocrinal, psychiatric, eye, cardiovascular and injury ailments.
The average insurance financing for male inpatient care of various ailments was ranged between Rs.906.6 and Rs. 10677.2. Similarly, for females, the average insurance financing was ranged between rupees 394.8 and 6063.2. The average insurance financing for inpatient care was higher for males than females (1.2 to 3.2 times) for all ailments except for blood, respiratory and musculoskeletal illness. The gender difference in insurance claim amount was significant for ailments like endocrinal, gastrointestinal and 'other' ailments.

Table 3.Socio-Economic Status (SES) stratified analysis of gender difference in Total Health Expense

\begin{tabular}{|c|c|c|c|c|c|c|c|c|c|}
\hline \multirow{3}{*}{ Aliment Type } & \multicolumn{9}{|c|}{ Average Total Health Expenses } \\
\hline & \multicolumn{3}{|c|}{ Low SES } & \multicolumn{3}{|c|}{ Middle SES } & \multicolumn{3}{|c|}{ High SES } \\
\hline & Male & Female & $\mathrm{p}$-value & Male & Female & $p$-value & Male & Female & p-value \\
\hline Infection & 7474 & 6321.6 & 0.007 & 10817.9 & 8644.4 & 0.0002 & 10392.1 & 8712.6 & 0.1 \\
\hline Cancer & 78137.4 & 41062.7 & 0.22 & 98837.2 & 65906.7 & 0.034 & 52250.5 & 40658.4 & 0.26 \\
\hline Blood disorders & 16224.8 & 11866.3 & 0.18 & 16174.5 & 22221.9 & 0.55 & 11414.7 & 14395.3 & 0.49 \\
\hline Endocrinal disorders & 16158 & 12001.2 & 0.12 & 21555.2 & 14399.9 & 0.01 & 18004.4 & 19426.3 & 0.79 \\
\hline Psychiatric disorders & 26986.9 & 15781 & 0.0003 & 32763.6 & 23357.3 & 0.006 & 24578.5 & 20929.1 & 0.43 \\
\hline Eye diseases & 8818 & 6483.9 & 0.026 & 12699.3 & 12699.3 & 0.47 & 10818.8 & 11490.6 & 0.76 \\
\hline Ear diseases & 12642.7 & 13477.7 & 0.84 & 17998.4 & 19547 & 0.7 & 9808.1 & 17946.2 & 0.3 \\
\hline $\begin{array}{l}\text { Cardiovascular } \\
\text { disorders }\end{array}$ & 40111.2 & 17158.2 & 0.0001 & 46592 & 28935.3 & 0.0001 & 40550.2 & 33299.1 & 0.31 \\
\hline Respiratory disorders & 10685.3 & 9664.9 & 0.49 & 16573.2 & 15251 & 0.53 & 12295.2 & 15037.5 & 0.29 \\
\hline $\begin{array}{l}\text { Gastrointestinal } \\
\text { disorders }\end{array}$ & 15822 & 14227 & 0.18 & 20123.9 & 19933.1 & 0.89 & 21516.9 & 17393.2 & 0.084 \\
\hline Skin diseases & 15131.1 & 11767.5 & 0.42 & 14678.1 & 13646.8 & 0.71 & 25610.5 & 15714.3 & 0.3 \\
\hline $\begin{array}{c}\text { Musculoskeletal } \\
\text { disorders }\end{array}$ & 16584.1 & 14529.4 & 0.28 & 30015.2 & 32365.3 & 0.54 & 24621.7 & 28752.4 & 0.54 \\
\hline $\begin{array}{l}\text { Genitourinary } \\
\text { disorders }\end{array}$ & 24275.6 & 18697.7 & 0.046 & 35760.3 & 26230.1 & 0.068 & 27060.6 & 24604.5 & 0.59 \\
\hline Sick new born & 12400.6 & 13878.6 & 0.75 & 22852.9 & 20468.3 & 0.67 & 24537.6 & 10378.8 & 0.093 \\
\hline Injuries & 22468.8 & 17207.8 & 0.022 & 35361.3 & 27063.5 & 0.015 & 26696.4 & 23577.3 & 0.46 \\
\hline Others & 17507.8 & 19478.5 & 0.59 & 32281.7 & 27636.4 & 0.36 & 32103.7 & 14555.4 & 0.001 \\
\hline
\end{tabular}


The average OOPEs for male inpatient care of various ailments were ranged between Rs. 9141.8 and Rs. 75180.6. Similarly, for females, the average OOPEs ranged between Rs. 7459.3 and Rs. 49583.2. The average out of pocket expenses for inpatient care was higher for males than females (1.03 to 1.17 times) for all ailments except for blood, ear and musculoskeletal disorders. The gender difference in out of pocket expenses was significant for ailments like infection, cancer, endocrinal, psychiatric, cardiovascular, genitourinary disorders and injuries.

The average total health expenses in low SES group, middle SES group, high SES for male inpatient care of various ailments was ranged between Rs. 7474 and Rs. 78137.4; Rs. 10817.9 and Rs. 98837.2 and Rs. 9808.1 and Rs. 52250.5 respectively. Similarly, for females in low, middle and high SES group, the average total health expenses were ranged between Rs. 6321.6 and Rs. 41062.7; Rs. 8644.4 and Rs. 65906.7 and Rs. 8712.6 and Rs. 40658.4 respectively. The average total health expense for inpatient care was higher for males than females in all three SES groups for all ailments except certain specified ailments in each SES group i.e. ear diseases, sick newborn and 'other' illnesses in low
SES group, blood, ear and musculoskeletal disorders in middle SES and blood, endocrinal, eye, ear, respiratory and musculoskeletal disorders in high SES. The gender difference in average total health expenses in lower SES was significant for ailments like infection, psychiatric, eye, cardiovascular, genitourinary ailments and injuries. Similarly, in middle SES the gender difference was significant for ailments like infection, cancer, endocrinal, psychiatric, cardiovascular disorders and injuries. The gender disparity was significant only for 'other' ailments in high SES group.

The average insurance financing for male inpatient care of various ailments among lower, middle and high SES groups was ranged between rupees 0- 2706.2; 129 -18353.8 and $0-5433.8$ respectively. Similarly for females in low, middle and high SES groups, the average insurance financing was ranged between rupees 0 - 1024.4; 0 - 9278.4 and 0- 2376.8 respectively. The average total insurance financing in lower SES for inpatient care was usually higher for males than females in low (1.3to 19.9 times), middle (1.2 to 3.4 times) and high (1.1 to 2.4 times) SES groups, for all ailments except for certain aliments as given in the table 4 .

Table 4.SES stratified analysis of gender difference in financing through insurance

\begin{tabular}{|c|c|c|c|c|c|c|c|c|c|}
\hline \multirow{3}{*}{ Aliment Type } & \multicolumn{9}{|c|}{ Average Amount of Insurance Financing } \\
\hline & \multicolumn{3}{|c|}{ Low SES } & \multicolumn{3}{|c|}{ Middle SES } & \multicolumn{3}{|c|}{ High SES } \\
\hline & Male & Female & p-value & Male & Female & $p$-value & Male & Female & p-value \\
\hline Infection & 130.7 & 163.7 & 0.52 & 1586.2 & 578.7 & 0.35 & 282.5 & 258.8 & 0.86 \\
\hline Cancer & 955.6 & 1024.4 & 0.95 & 18353.8 & 9278.4 & 0.2 & 80 & 2376.8 & 0.15 \\
\hline Blood disorders & 0 & 156.1 & 0.39 & 421.4 & 337 & 0.78 & 0 & 364.3 & 0.28 \\
\hline Endocrinal disorders & 1165.1 & 58.6 & 0.085 & 1827.5 & 1311.2 & 0.5 & 4090.9 & 0 & 0.021 \\
\hline Psychiatric disorders & 677.2 & 528.7 & 0.81 & 2413 & 526.9 & 0.019 & 518 & 1360.2 & 0.47 \\
\hline Eye diseases & 415.8 & 500 & 0.77 & 1357.4 & 1059.8 & 0.47 & 612.1 & 340.8 & 0.46 \\
\hline Ear diseases & 1090.9 & 116.7 & 0.31 & 411.5 & 703.4 & 0.63 & 0 & 115.4 & 0.48 \\
\hline $\begin{array}{c}\text { Cardiovascular } \\
\text { disorders }\end{array}$ & 2706.2 & 294.1 & 0.17 & 4239 & 3456.3 & 0.5 & 5433.8 & 1258.6 & 0.061 \\
\hline Respiratory disorders & 214 & 484 & 0.34 & 1113.1 & 1339.1 & 0.71 & 467.2 & 0 & 0.2 \\
\hline $\begin{array}{l}\text { Gastrointestinal } \\
\text { disorders }\end{array}$ & 352.5 & 523.8 & 0.5 & 2300.9 & 866.4 & 0.012 & 1198.6 & 708.4 & 0.46 \\
\hline Skin diseases & 6.9 & 286.6 & 0.099 & 2243.3 & 1143.3 & 0.44 & 0 & & \\
\hline $\begin{array}{l}\text { Musculoskeletal } \\
\text { disorders }\end{array}$ & 305.3 & 298.6 & 0.98 & 3123.4 & 4596.3 & 0.36 & 177.8 & 469.7 & 0.35 \\
\hline $\begin{array}{l}\text { Genitourinary } \\
\text { disorders }\end{array}$ & 735.1 & 348.5 & 0.18 & 7747.9 & 2782 & 0.3 & 1438.8 & 1482.1 & 0.97 \\
\hline Sick newborn & 13.5 & 0 & 0.37 & 129 & 0 & 0.45 & 235.3 & 0 & 0.39 \\
\hline Injuries & 730.5 & 310.1 & 0.45 & 2625.4 & 1688.1 & 0.23 & 1002.8 & 880.4 & 0.85 \\
\hline Other & 130.3 & 199.2 & 0.68 & 4602.1 & 1363.1 & 0.015 & 343 & 26.8 & 0.33 \\
\hline
\end{tabular}


Table 5.SES stratified analysis of gender difference in OOPEs

\begin{tabular}{|c|c|c|c|c|c|c|c|c|c|}
\hline \multirow{2}{*}{ Aliment Type } & \multicolumn{9}{|c|}{ OOPE } \\
\cline { 2 - 10 } & \multicolumn{3}{|c|}{ Low SES } & \multicolumn{3}{c|}{ Middle SES } & \multicolumn{3}{c|}{ High SES } \\
\cline { 2 - 10 } & Male & \multicolumn{2}{|c|}{ Female } & Male & \multicolumn{2}{|c|}{ Female } & Male & \multicolumn{2}{c|}{ Female } \\
\cline { 2 - 10 } & Mean & Mean & $\mathbf{p}$-value & Mean & Mean & p-value & Mean & Mean & p-value \\
\hline Infection & 7343.3 & 6157.9 & 0.005 & 10115.2 & 8077.5 & 0.0002 & 10109.5 & 8453.7 & 0.1 \\
\hline Cancer & 77181.8 & 40038.3 & 0.22 & 80483.4 & 56700.2 & 0.063 & 52170.5 & 38281.6 & 0.17 \\
\hline Blood disorders & 16224.8 & 11710.1 & 0.17 & 15753.1 & 21884.9 & 0.54 & 11414.7 & 14031 & 0.55 \\
\hline Endocrinal disorders & 15064.2 & 11946.9 & 0.23 & 19727.7 & 13088.7 & 0.01 & 13913.5 & 19426.3 & 0.24 \\
\hline Psychiatric disorders & 26309.7 & 15252.3 & 0.0002 & 30350.6 & 22830.4 & 0.022 & 24060.5 & 19568.9 & 0.32 \\
\hline Eye diseases & 8402.2 & 5983.9 & 0.018 & 11341.8 & 10904 & 0.65 & 10206.7 & 11149.8 & 0.67 \\
\hline Ear diseases & 11551.8 & 13361 & 0.65 & 17586.8 & 18843.6 & 0.75 & 9808.1 & 17830.8 & 0.31 \\
\hline $\begin{array}{c}\text { Cardiovascular } \\
\text { disorders }\end{array}$ & 37404.9 & 16864.2 & 0.0001 & 42482.1 & 25479 & 0.0001 & 35116.4 & 32063.4 & 0.66 \\
\hline $\begin{array}{c}\text { Respiratory } \\
\text { disorders }\end{array}$ & 10471.3 & 9180.9 & 0.37 & 15460.1 & 13912 & 0.43 & 11828 & 15037.5 & 0.21 \\
\hline $\begin{array}{c}\text { Gastrointestinal } \\
\text { disorders }\end{array}$ & 15501.5 & 13703.9 & 0.12 & 17901.6 & 19070.1 & 0.37 & 20329.8 & 16684.9 & 0.11 \\
\hline Skin diseases & 15124.2 & 11480.9 & 0.38 & 12434.8 & 12503.6 & 0.98 & 25610.5 & 15714.3 & 0.3 \\
\hline $\begin{array}{c}\text { Musculoskeletal } \\
\text { disorders }\end{array}$ & 16278.9 & 14230.7 & 0.28 & 26891.8 & 27769 & 0.8 & 24443.9 & 28282.7 & 0.57 \\
\hline $\begin{array}{c}\text { Genitourinary } \\
\text { disorders }\end{array}$ & 23540.5 & 18350.2 & 0.057 & 28046.3 & 23451.5 & 0.037 & 25621.7 & 23122.4 & 0.56 \\
\hline Sick newborn & 12387.1 & 13878.6 & 0.75 & 22723.9 & 20468.3 & 0.69 & 24302.4 & 10378.8 & 0.099 \\
\hline $\begin{array}{c}\text { Injuries } \\
\text { Others }\end{array}$ & 21812.1 & 16897.7 & 0.029 & 32769.9 & 25375.4 & 0.024 & 25693.6 & 22696.9 & 0.47 \\
\hline & 17377.5 & 19279.3 & 0.61 & 27781.4 & 26273.3 & 0.76 & 31760.6 & 14528.6 & 0.002 \\
\hline
\end{tabular}

The average OOPEs for male inpatient care of various ailments in low, middle SES and high SES groups was ranged between Rs. 7343.3 and Rs. 77181.8; Rs. 10115.2 and Rs. 80483.4 and Rs. 9808.1 and Rs. 52170.5 respectively (table not given). Similarly, for females, the average OOPEs among low, middle and high SES groups ranged between Rs. 5983.9 and Rs. 40038.3 ; Rs. 8077.5 and Rs. 56700.2 and Rs. 8453.7 and Rs. 38281.6 respectively. The average OOPEs for inpatient care was higher for males than females in low (1.1 to 2.2 times), middle (1.1 to 1.7 times) and high (1.1 to 2.3 times) SES groupsfor all ailments except for ear, sick newborn and other ailments in low SES group; for blood, ear, gastrointestinal, skin and musculoskeletal illness in middle SES group and for blood, endocrinal, eye, ear, respiratory and musculoskeletal disorders in high SES group. The gender difference in average OOPEs in lower SES was significant for ailments like infection, psychiatric, eye, cardiovascular, genitourinary and injury, similarly in middle SES group was significant for ailments like infection, endocrinal, psychiatric, cardiovascular, Genitourinary disorders and injuries and in high SES group was significant for sick newborn and 'other' ailments.

\section{Discussion}

Equity in healthcare is one of the important and most desired goals to be achieved for any society. Inequalities in healthcare are measured on the basis of health outcome, utilization pattern and level of OOPEs, between the nonpoor or poor, urban or rural, advantaged or disadvantaged and other socio-economic groups of the population. ${ }^{20}$ This study brings into focus healthcare inequalities in India that are based on social groups.

In this study, the burden of OOPEs is higher among inpatients from low and middle SES groups than that of high SES. This highlights both inequity and inequality among various SES groups. A study on rural cancer patients in a public tertiary hospital in an eastern Indian state, shows that expenditure on female adults is significantly less than on male adults, and that about $73 \%$ of the difference can be drawn back to gender discrimination the biggest reason for 
the difference in expenditure is attributed to differences in treatment seeking and medical expenditures before coming to the tertiary center. ${ }^{21}$ A small study conducted in rural Uttar Pradesh showed that among households with male children, the average expenditure on health care during the neonatal period was nearly fourfold that of households with females. Further, households with female newborns used cheaper public care providers, whereas households with male newborns preferred private providers (although unqualified) as these were perceived to deliver satisfactory care. $^{22}$

The average OOPEs for majority of ailments is higher for males than their female counterparts. Most importantly, wherever the average OOPEs for females is higher than their male counterparts in select ailments as highlighted above, the statistical significance is nil. Therefore, considering gender difference and statistical significance, the average OOPEs is always higher for males than females. This highlights higher healthcare spending for males is higher than their female counterparts. The probability of financing the hospitalization of boys through borrowing, sale of assets, and helps from relatives, is much higher than it is for girls. ${ }^{27,29}$ This gender disparity may be due to differential health-seeking behaviour, cultural behaviour, accessibility and availability of services; ${ }^{20}$ as well as may be due to malefemale differences in demographic, socio-economic and health care-related factors such as lack of women focused policies and budgeting. ${ }^{6,29}$

In general, women in developed countries are more aware about their health use more health-care facilities and preventive care ${ }^{24}$ and therefore, spend more on their health. ${ }^{25,26}$ But in countries like India and China, where a complex web of poverty, social hierarchy and deep-rooted patriarchal structure eliminates women's health from the household priority list, women often invest more of their time in household activities or work that is not directly linked to economic outcomes. ${ }^{27-29}$

Therefore, they may postpone meeting their own health needs to meet those of male family members directly involved in earning income $\mathrm{e}^{23-25}$ and prioritize the health of male members over their own. ${ }^{6,23}$ This is still an example of gender discrimination rather than gender equity since women's indirect contribution to household income through household chores and care giving remains unaccounted. In the absence of robust social protection schemes, poor families often mitigate health-related out-of-pocket expenditure by compromising on the health needs of female family members. ${ }^{6}$ On the other hand, in non-poor families, women have less power to bargain on their needs due to lack of property ownership, lack of income earning means, lack of community support, and ongoing social norms and perceptions. ${ }^{6}$ Thus, the gender differential in
HCE in India is perhaps the result of powerful synergies between socio-economic status and patriarchal values.

\section{Conclusions}

Gender disparity in total health expenditure, financing through insurance and out-of-pocket expenses for various ailments is a concern. In a developing country like India, where majority of the population spends on healthcare services from their own pockets, higher government spending on health is essential, so that the population can be protected from distress financing and catastrophic health expenses. The gendered pattern of healthcare expenditure requires differential pricing of healthcare services to promote gender equity, which needs to be explored. As far as OOPEs is concerned, higher OOPE among male than their female counterparts require further study to explore the determinants including variation in treatment quality if any. However, designing a financial protection mechanism requires a deeper understanding of both the absolute and relative amounts of the financial burden of OOPE on the households. Gender analysis of health financing indicators should be given priority while evaluating health policies and programmes.

\section{List of Abbreviations}

FSUs: First-Stage Units

HCE: Health Care Expenditure

NSSO: National Sample Survey Organization

OOPEs: Out-of-Pocket Expenses

SES: Socio-Economic Status

\section{Conflict of Interest: None}

\section{References}

1. Bongaarts J, Guilmoto CZ. How Many More Missing Women? Excess Female Mortality and Prenatal Sex Selection, 1970-2050. Popul Dev Rev 2015; 41(2): 241269. Available from: https://www.popcouncil.org/ research/how-many-more-missing-women-excessfemale-mortality-and-prenatal-sex-select [Google Scholar].

2. Kaul T. Intra-household allocation of educational expenses: Gender discrimination and investing in the future. World Dev 2018; 104(C): 336-343. Available from: https://ideas.repec.org/a/eee/wdevel/v104y 2018icp336-343.html [Google Scholar].

3. Mukherjee R. Selective Gender Differences in Child Health among Small Families in Eight Replacement Fertility States of India. 2014: 25. Available from https:// paa2014.princeton.edu/papers/142335.

4. Corsi DJ, Bassani DG, Kumar R et al. Gender inequity and age-appropriate immunization coverage in India from 1992 to 2006. BMC Int Health Hum Rights 2009; 9(Suppl 
1): S3. Available from: https://bmcinthealthhumrights. biomedcentral.com/articles/10.1186/1472-698X-9S1-S3 [PubMed/ Google Scholar].

5. Asfaw A, Klasen S, Lamanna F. Intra-Household Gender Disparities in Children's Medical Care before Death in India. Rochester, NY: Social Science Research Network; 2007. Report No.: ID 964967. Available from: https:// papers.ssrn.com/abstract=964967.

6. Nandita Saikia M. Gender Difference in Health-Care Expenditure: Evidence from India Human Development Survey. PLOS ONE 2016; 11(7). Available from: https:// www.ncbi.nlm.nih.gov/pmc/articles/PMC4938214/.

7. Singh S. The State of Gender Inequality in India. Gender Studies 2017; 15(1): 139-157. Available from: https:// content.sciendo.com/configurable/contentpage/ journals\$002fgenst\$002f15\$002f1\$002farticle-p139. $\mathrm{xml}$.

8. International Labour Organization. World of Work Report 2014. Geneva: ILO, 2014. Available from: https:// www.ilo.org/global/research/global-reports/world-ofwork/2014/lang--en/index.htm.

9. Abeysinghe T, Himani, Lim J. Singapore's healthcare financing: Some challenges. 18. Available from: https:// pdfs.semanticscholar.org/1427/bb2ffd7a2d3b1805 659f9b1ce50d7127a21d.pdf.

10. Graeve DD, Schokkaert E, Cantillon B, Ourti TV, Kerstens B. Equity in the Finance of Healthcare: Summary Promoters: 10. Available from: https://www. semanticscholar.org/paper/Equity-in-the-Finance-ofHealthcare-\%3A-Summary-\%3A-Graeve-Schokkaert/5 b517de3537fb032acb7409defbec45b0c48d570.

11. Modugu HR, Kumar M, Kumar A, Millett C. State and socio-demographic group variation in out-ofpocket expenditure, borrowings and Janani Suraksha Yojana (JSY) programme use for birth deliveries in India. BMC Public Health 2012; 12: 1048. Available from: https://bmcpublichealth.biomedcentral.com/ articles/10.1186/1471-2458-12-1048.

12. Selvaraj S, Karan AK. Deepening Health Insecurity in India: Evidence from National Sample Surveys since 1980s. 2009; 44(40): 55-60. Available from: http:// re.indiaenvironmentportal.org.in/files/Deepening\%20 Health\%20Insecurity\%20in\%20India.pdf [Google Scholar/ ResearchGate].

13. Moradhvaj, Saikia N. Gender disparities in HealthCare Expenditure (HCE) and financing strategies for in-patient care in India. SSM - Popul Health 2019; 100372. Available from: https://www.sciencedirect. com/science/article/pii/S2352827318302787.

14. Maharana B, Ladusingh L. Gender Disparity in Health and Food Expenditure in India among Elderly. International Journal of Population Research 2014; 150105: 8. Available from: https://www.hindawi. com/journals/ijpr/2014/150105/ [DOI: http://dx.doi. org/10.1155/2014/150105/ Google Scholar].

15. Wagstaff A, van Doorslaer E. Chapter 34 Equity in health care finance and delivery. In: Handbook of Health Economics Elsevier 2000; 1803-1862. Available from: http://www.sciencedirect.com/science/article/pii/ S1574006400800475.

16. Culyer AJ, van Doorslaer E, Wagstaff A. Utilisation as a measure of equity by Mooney, Hall, Donaldson and Gerard. J Health Econ 1992; 11(1): 93-98. Available from: [PubMed/ Google Scholar].

17. India - Social Consumption: Health, NSS 71st Round : Jan - June 2014 . Available from: http://mail.mospi.gov. in/index.php/catalog/161/related_materials.

18. RStudio. R Studio. 2014. Available from: https://www. rstudio.com/.

19. Dwivedi R, Pradhan J. Does equity in healthcare spending exist among Indian states? Explaining regional variations from national sample survey data. Int J Equity Health 2017; 16(1): 15. Available from: https:// equityhealthj.biomedcentral.com/articles/10.1186/ s12939-017-0517-y [PubMed/ Google Scholar].

20. Galdas PM, Cheater F, Marshall P. Men and health helpseeking behaviour: literature review. J Adv Nurs 2005; 49(6): 616-623. [PubMed/ Google Scholar].

21. Owens G. Gender Differences in Health Care Expenditures, Resource Utilization, and Quality of Care. J Manag Care Pharm 2008; 14(3 Supp A): 2-6. [PubMed/ Google Scholar].

22. Alemayehu B, Warner KE. The Lifetime Distribution of Health Care Costs. Health Serv Res 2004; 39(3): $627-$ 642. [PubMed/ Google Scholar].

23. Song Y, Bian Y. Gender differences in the use of health care in China: cross-sectional analysis. Int J Equity Health 2014; 13: 8. [PubMed/ Google Scholar]. 